\title{
Research on Key Competences Needs of Volunteers in Ecological Citizen Science Projects based on Grounded Theory
}

\author{
Ziyue Li \\ School of Nanjing University of Science and Technology, Nanjing 210000, China \\ lzyhealer@163.com
}

Keywords: Grounded Theory, Key Competences, Ecology, Citizen Science

\begin{abstract}
This paper selects 5 typical cases of ecological citizen science projects and tries to use grounded theory analysis to explore the core quality requirements of ecological citizen science projects on volunteers. The study obtained 56 initial concepts, 12 categories and their corresponding knowledge, skills, physical and mental will and values of 4 main categories. The results of this study can play a role in the assessment of the impact of ecological citizen science projects on the quality of volunteers, and also provide help for the recruitment of volunteers for citizen science projects.
\end{abstract}

\section{Introduction}

With the rapid development of Internet technology, the Internet is no longer just a tool for media organizations to publish information and for users to browse information, but also a platform focusing on user-provided content [1]. This orientation encourages the connection and cooperation between users, multi-directional communication and exchange, and innovative thinking of advance technological progress, etc., thus making the Internet a platform integrating public wisdom and power [2]. In the context of Internet group collaboration, citizen science projects based on scientific research crowdsourcing model can well avoid the constraints of traditional scientific research, and some scientific research projects with high cost, long time and large personnel demand can get good solutions. The citizen science project has become a new kind of informal education project. Brossard [3] found in his research on THE TBN project in 2005 that the project increased the volunteers' knowledge of birds and their understanding of science. Since then, Bonney[4] and Crall[5] have also pointed out that citizen science projects can increase volunteers' awareness of scientific knowledge and processes as well as some deeper meanings. But these previous studies have raised the same question: There is no proper scale to assess the quality of the volunteers. The ATOSS scale is an organizational science Attitude scale developed by the National Science Foundation of the United States. Most of the existing researches are also based on this scale to evaluate the public's scientific attitude. Bonney used MATOSS, a modified version of ATOSS, in his study. Later, Crall also used MATOSS scales, but the results did not live up to expectations. Therefore, it is necessary to develop an appropriate assessment framework to assess the quality of volunteers, which can play a role in the study of the impact of citizen science projects on the quality of volunteers, and also provide assistance for the recruitment of volunteers for citizen science projects.

In view of this, this paper mainly uses the research method of grounded theory in the field of ecology, a total of 5 typical citizen science projects in the field of ecology to demand the key competence of volunteers, and analyzes the coding results, providing a reference for the development of the key competence evaluation framework and scale of volunteers in ecological citizen science projects.

\section{Review of the literature}

\subsection{Review of citizen science research in ecology}


Citizen science, also known as crowd science, community science and public participation in scientific research, refers to the process in which the public participate in scientific activities as researchers [6]. The concept of citizen science originated in the West and was formally proposed by Alan Iriwn, a British scientific sociologist, in his publication Ctizen Science in 1995. Iriwn[7] defines citizen science as the direct participation of the public in the scientific process, based on the need for openness in science and openness in science policy.

Citizen Scientist is closely associated with Citizen Science. "Citizen scientists" refers to the actual to participate in scientific research volunteers, most of them just amateur, is not really a scientist, to be involved in the public foreign volunteers for the science project in white, with higher education and is the main part of the rich, they volunteer to help for scientific research, in most cases there is no reward [4]. In most citizen science projects, volunteers are only responsible for data collection and collation, and do not participate in data analysis or scientific paper writing. However, their information collection is a crucial part of the project, the foundation of scientific research, and indispensable. The accuracy of data collected by volunteers is indeed lower than that of data collected by scientists, but volunteers are able to provide data over a larger space and time range [8].

Ecological research is characterized by large scale, long cycle and high complexity. It is difficult for ecological research to collect data in a long time and large space, but citizen science can solve the problems existing in ecological research [10]. Citizen science projects in ecology cover a wide range of topics, from species research to environmental protection to species conservation. In 1900, the National Audubon Society launched the Christmas Bird Count (CBC), a program of more than 50, 000 volunteers each year that collects data for Bird studies. In 2006, the National Institute for Invasive Species Science (NIISS) launched a citizen science project on invasive species research, which fully coordinated data collection among professional scientists, natural resource managers and citizen scientists. In 2017, the Cat League (CFCA) launched the "Take the Leopard home" project, hoping to bring the North China leopard back to its hometown in Beijing through long-term efforts. These projects make full use of the role that volunteers can play and solve the problems of ecological research. However, these projects are highly specialized, requiring volunteers to have or be able to learn relevant knowledge and skills and to persevere for a period of time.

\subsection{Research on the literacy of volunteers in ecological citizen science projects}

"Literacy" is closely connected with education topic since ancient times, which is training and practice for a moral accomplishment. The difference between "key competences" and "literacy" is the "key" [9]. The research on the literacy of volunteers in ecological citizen science projects both at home and abroad mainly focus on scientific literacy. At home, the research on the literacy of volunteers in ecological citizen science projects is still in the blank, and higher awareness of this is mainly in Europe and the United States and other developed countries, though controversial, but having periodic achievement. To this day, the research on the scientific literacy of volunteers mainly focuses on three aspects: the measurement of the change of the scientific literacy of volunteers, the measurement tools of the change of the scientific literacy of volunteers, and the influencing factors of the change of the scientific literacy of volunteers.

The author collected and analyzed the information about the key competences needs of volunteers in five projects: The Great Backyard Bird Count, Evolution MegaLab, Taking Leopards Home, Chasing in the Wilderness, and Protecting the White Bird Lake Wetland.

\section{Case description}

\subsection{Collection and selection of cases}

There have been many mature projects in ecological citizen science both at home and abroad. In this paper, case search is mainly conducted through two channels: the database of academic journals and searching citizen science related portal website and activity news by search engine. Finally, 15 citizen science projects were collected by means of snowballing, and then selected these projects. 
Finally, 5 typical cases of ecological citizen science projects at home and abroad were left. The screening rules are as follows :(1) the development of the case project is mature and stable enough with certain achievements and a project proprietary platform to collect fine-grained information about the project's requirements on the key competence of volunteers;(2) To ensure that the cases include domestic and foreign citizen science projects and that the cases are representative (Table 1).

\subsection{Basic overview of the cases}

This paper mainly describes the cases from four aspects: Project name, Project overview, Project environment, volunteer's task, task difficulty, Research filed (Table 1).

Table1 Basic overview of the cases

\begin{tabular}{|c|c|c|c|c|c|}
\hline Project name & Project outline & $\begin{array}{l}\text { Project } \\
\text { Environment }\end{array}$ & $\begin{array}{ll}\text { Tasks } & \text { for } \\
\text { volunteers } & \end{array}$ & $\begin{array}{l}\text { Difficulty } \\
\text { of the task }\end{array}$ & $\begin{array}{ll}\text { Field } & \text { of } \\
\text { Research }\end{array}$ \\
\hline $\begin{array}{l}\text { Evolution } \\
\text { MegaLab }\end{array}$ & $\begin{array}{l}\text { Capture and identify the strip } \\
\text { snail, and the number of } \\
\text { snails, } \\
\text { characteristics and other } \\
\text { information records }\end{array}$ & $\begin{array}{l}\text { Online } \\
\text { Offline }\end{array}$ & $\begin{array}{lr}\text { Capture } & \text { and } \\
\text { identify } & \text { strip } \\
\text { snails } & \end{array}$ & Medium & $\begin{array}{l}\text { Investigation } \\
\text { and study of } \\
\text { species }\end{array}$ \\
\hline $\begin{array}{l}\text { Take the } \\
\text { leopard home }\end{array}$ & $\begin{array}{l}\text { To investigate the } \\
\text { distribution history and } \\
\text { current situation of North } \\
\text { China in the northern section } \\
\text { of Taihang Mountain and } \\
\text { evaluate the potential of } \\
\text { restoring the habitat of North } \\
\text { China leopard in baihuashan } \\
\text { Reserve and surrounding } \\
\text { mountains }\end{array}$ & $\begin{array}{l}\text { Online } \\
\text { Offline }\end{array}$ & $\begin{array}{l}\text { Restore the } \\
\text { wilderness, } \\
\text { protect the } \\
\text { North China } \\
\text { leopard, bring } \\
\text { the leopard } \\
\text { home }\end{array}$ & Difficult & $\begin{array}{l}\text { Species } \\
\text { conservation }\end{array}$ \\
\hline $\begin{array}{l}\text { Global } \\
\text { Learning and } \\
\text { Observations to } \\
\text { Benefit the } \\
\text { Environment } \\
\end{array}$ & $\begin{array}{l}\text { Ecological environment } \\
\text { monitoring }\end{array}$ & $\begin{array}{l}\text { Online } \\
\text { Offline }\end{array}$ & $\begin{array}{l}\text { Observe air, } \\
\text { soil, water }\end{array}$ & Difficult & $\begin{array}{l}\text { Environment } \\
\text { surveillance }\end{array}$ \\
\hline $\begin{array}{lr}\text { The } & \text { Great } \\
\text { Backyard } & \text { Bird } \\
\text { Count } & \end{array}$ & $\begin{array}{l}\text { Observe and record nearby } \\
\text { birds' activities, species, } \\
\text { number and physical } \\
\text { characteristics }\end{array}$ & $\begin{array}{l}\text { Online } \\
\text { Offline }\end{array}$ & $\begin{array}{l}\text { Observe and } \\
\text { count the } \\
\text { number of } \\
\text { birds in the } \\
\text { area }\end{array}$ & Difficult & Ornithology \\
\hline $\begin{array}{l}\text { Protection of } \\
\text { the White Bird } \\
\text { Lake Wetland }\end{array}$ & $\begin{array}{l}\text { Promote protection } \\
\text { knowledge of birds and call } \\
\text { for the protection of white } \\
\text { Bird Lake birds and their } \\
\text { living environment }\end{array}$ & $\begin{array}{l}\text { Online } \\
\text { Offline }\end{array}$ & $\begin{array}{ll}\begin{array}{l}\text { Protect } \\
\text { and }\end{array} & \text { birds } \\
\text { habitat } & \end{array}$ & Medium & $\begin{array}{l}\text { Environmental } \\
\text { protection }\end{array}$ \\
\hline
\end{tabular}

The tasks of ecological citizen science are generally medium or difficult, which are more complex than other types of citizen science projects, and requiring higher professional knowledge and skills. For example, volunteers in the Great Backyard Bird Count project not only need to know ornithology, count birds by classification, but also need to observe carefully. Tasks of the GLOBE are difficult. Volunteers need to be able to use tools to observe the surrounding environment such as air, soil, water. Volunteers in the take The Leopard Home program need to be able to survive in the wild and use infrared cameras.

\section{Data analysis}

\subsection{Methods}

The key competences of volunteers were collected through reading relevant information, 
browsing the project site and search engines. Then encoded the informations, Conceptualized, categorized and categorized the key competences needs. The coding process mainly refers to the Eu Key competence Framework and The Chinese Students Key competence Evaluation Framework.

In order to ensure the reliability and accuracy of the coding results, the author invited two graduate students to classify and code the core qualities required for citizen science projects in different fields. The author then analyzed and discussed the coding results.

\subsection{Open coding}

The purpose of Open Coding is to identify the initial concept and its attributes and dimensions from the data. The coders in this article broke down the raw data in detail, then eliminated the initial concept that the number of repetitions is less than three, getting 56 initial concepts(a1 a56).

And then getted 12 categories (A1 A12) by integrating the 56 initial concepts(Table 2).

Table 2 Results of encoding

\begin{tabular}{|c|c|c|c|}
\hline Main category & Category & Connotation of the category & Initial concept (partial) \\
\hline \multirow{3}{*}{ B1 Knowledge } & $\begin{array}{l}\text { A1 Basic } \\
\text { Knowledge }\end{array}$ & $\begin{array}{l}\text { Volunteers need to have basic } \\
\text { knowledge such as literacy and } \\
\text { English reading skills }\end{array}$ & $\begin{array}{l}\text { a1 Excellent writing } \\
\text { a3 Translate books }\end{array}$ \\
\hline & $\begin{array}{l}\text { A2 Domain } \\
\text { knowledge }\end{array}$ & $\begin{array}{l}\text { Volunteers need to have expertise in } \\
\text { specific species that the project } \\
\text { focuses on, such as ornithology and } \\
\text { geography }\end{array}$ & $\begin{array}{l}\text { a4 Biological knowledge } \\
\text { a5 Geographical } \\
\text { knowledge }\end{array}$ \\
\hline & A3 Experience & $\begin{array}{l}\text { Volunteers need to have some } \\
\text { experience in relevant projects will } \\
\text { make volunteers more efficient in new } \\
\text { projects and accumulate experience in } \\
\text { projects will also make tasks go } \\
\text { smoothly }\end{array}$ & $\begin{array}{l}\text { a6 Experience } \\
\text { accumulation }\end{array}$ \\
\hline \multirow{5}{*}{ B2 Skill } & $\begin{array}{l}\text { A4 Research } \\
\text { Ability }\end{array}$ & $\begin{array}{l}\text { Volunteers can be able to use specific } \\
\text { tools provided by the project side for } \\
\text { water quality measurement, veterinary } \\
\text { monitoring and environmental } \\
\text { monitoring }\end{array}$ & $\begin{array}{l}\text { a7 Water Quality } \\
\text { determination } \\
\text { a9 Questionnaire survey }\end{array}$ \\
\hline & $\begin{array}{l}\text { A5 Information } \\
\text { technology }\end{array}$ & $\begin{array}{l}\text { Volunteers need to have basic } \\
\text { computer skills, such as information } \\
\text { retrieval and data collection, collation, } \\
\text { analysis }\end{array}$ & $\begin{array}{l}\text { a16 Data Collection, a17 } \\
\text { Data record } \\
\text { a18 Data classification }\end{array}$ \\
\hline & A6 Learning ability & $\begin{array}{l}\text { Volunteers can be able to seriously } \\
\text { participate in the project training, learn } \\
\text { the rules and regulations of the projec }\end{array}$ & $\begin{array}{l}\text { a27 Understand project } \\
\text { background } \\
\text { a31 Participate in training }\end{array}$ \\
\hline & $\begin{array}{l}\text { A7 Collaboration } \\
\text { ability }\end{array}$ & $\begin{array}{l}\text { Volunteers need to communicate with } \\
\text { project team members in a timely } \\
\text { manner, help each other and cooperate } \\
\text { to complete tasks }\end{array}$ & $\begin{array}{l}\text { a36 Organization and } \\
\text { coordination ability } \\
\text { a37 Harmonious } \\
\text { coexistence }\end{array}$ \\
\hline & A8 Wild survival & $\begin{array}{l}\text { Volunteers need first aid skills in the } \\
\text { wild, motor skills and the ability to } \\
\text { avoid dangerous species }\end{array}$ & $\begin{array}{l}\text { a39 Motor Skills } \\
\text { a40 First aid skills }\end{array}$ \\
\hline \multirow[b]{2}{*}{$\begin{array}{l}\text { B3 The will of } \\
\text { body and mind }\end{array}$} & A9 Physical fitness & $\begin{array}{l}\text { Volunteers need to be physically fit } \\
\text { and able to adapt to tough conditions }\end{array}$ & a41 Good health \\
\hline & $\begin{array}{l}\text { A10 The spirit of } \\
\text { discovery }\end{array}$ & $\begin{array}{l}\text { Volunteers need to have the spirit of } \\
\text { not fearing hardship, courage, } \\
\text { fearlessness and exploration of the } \\
\text { unknown }\end{array}$ & a42 Fearless a43hardy \\
\hline \multirow[t]{2}{*}{ B4 Values } & $\begin{array}{l}\text { A11 Sense of } \\
\text { mission }\end{array}$ & $\begin{array}{l}\text { Volunteers should take every task } \\
\text { seriously and be patient, careful and } \\
\text { responsible in the task execution }\end{array}$ & $\begin{array}{l}\text { a44 Patience } \\
\text { a45 Carefulness, }\end{array}$ \\
\hline & $\begin{array}{l}\text { A12 Social } \\
\text { Responsibility }\end{array}$ & $\begin{array}{l}\text { Volunteers can be able to abide by the } \\
\text { relevant laws and regulations, love }\end{array}$ & $\begin{array}{l}\text { a49 Honesty } \\
\text { a50 Respect for nature }\end{array}$ \\
\hline
\end{tabular}




\begin{tabular}{|l|l|l|l|}
\hline & $\begin{array}{l}\text { animals and plants and their living } \\
\text { environment }\end{array}$ & \\
\hline
\end{tabular}

\subsection{Axial Coding}

Axial Coding is a summary of the relationship between categories based on open Coding. This paper summarizes the relations between the contents of the above 13 categories and the possible logical relations, and getted 4 main categories(B1 B4) (Table 2).

\subsection{Selective coding}

Selective coding is the integration of existing categories and the relationships among categories, mining the core categories, clarifying the story line and forming a theoretical framework. According to the purpose of this article, B1(knowledge), B2(skills), B3(The will of body and mind), B4(Values) were identified as core values.

\subsection{Theoretical saturation test}

At the same time, this study used another $1 / 3$ of the original data to test theoretical saturation, and found no new categories and relationships, so it can be considered that the theoretical model is saturated. The author thinks that this model can reflect the core qualities of volunteers in ecological citizen science projects to some extent, and sort out two logical relations, namely the ownership relationship and the intermediary relationship.

\section{Conclusion}

Through the encoding results, we can find that knowledge, skills, mental and physical will and values are the key competences required by ecological citizen science.Knowledge mainly includes basic English reading competence, and the knowledge of the ecology class. Competence of reading is the most basic requirements of volunteers to participate in any projects. Not volunteers of all projects must have the basis of English, but now citizen science projects are generally across the country. For volunteers who want to participate in some projects abroad, English is indispensable and English can help them to understand the project better. And project related knowledge of the ecology class is needed, such as: The Evolution MegaLab project requires volunteers with knowledge of the physical characteristics and habits of snails; The Big Backyard bird count project requires volunteers with knowledge of ornithology to identify different species of birds. Skills: With the advent of the information age, most of the current citizen science projects rely on digital platforms. The ability of volunteers to perform digital skills, such as information retrieval, data uploading and downloading, and data tagging, will greatly improve the efficiency of task completion. Secondly, some ecological public subjects need to perform tasks in the fields. Therefore, volunteers also need a certain ability to survive in the fields. Learning to learn is also needed for every volunteer to participate in each project. Before they do those tasks, they must try to know the background of the project, related technologies, and attend training. After mastering related knowledge, their participation can be more in-depth and project type can change from auxiliary type to the cooperative; Physical and mental will: A healthy body is the premise of any task. For difficult projects in the fields, good physical quality, brave and fearless spirit are indispensable. Values: When volunteers have a sense of mission for the tasks they perform, they will be more careful and efficient in task execution. Secondly, abiding by the rules and regulations of the project and the registration rules are the moral qualities that volunteers must have.

The theory, project design and operation management of citizen science have been developed maturely, and there have been many successful cases. This paper studies the key competence needs of volunteers for ecological citizen science projects, and the research results are of great significance to the development of ecological citizen science projects and the cultivation of the key competence of the public.

Volunteers may execute tasks wrongly, don't understand the research background, the collected data is not reliable, but there is not enough professional scientists in the project, the project team 
also can't afford the high cost, the public is free labor, skills and computing resources. If volunteers can be involved in the research, they can help to solve large space and long term citizen science projects. Volunteers can acquire new knowledge and skills which is also benefit from the projects [4].

\section{References}

[1] Yichong Niu, Yuxiang Zhao, Qinghua Zhao. A Preliminary Study on the operation mechanism of public science projects based on scientific research crowdsourcing model—-Take Evolution MegaLab project as an example [J]. Library and Information, 2017,61(01):5-13

[2] Zhaoyang Hu. Crowdsourcing Science: Public Participate in Innovation in the Context of Networked Communication [D].School of Chinese Science and Technology, 2015

[3] Brossard D, Lewenstein B, Bonney R. Scientific knowledge and altitude change: the impact of a citizen science project. Int J.Sci.Educ.27,1099-1121.

[4] Bonney R , Phillips T B , Ballard H L , et al. Can citizen science enhance public understanding of science?[J]. Public Understanding of Science, 2015.

[5] Crall A W, Jordan R, Holfelder K, et al. The impacts of an invasive species citizen science traning program on participant attitude, behavior, and science literacy[J]. Public Understanding of Science, 2013, 22(6):745-64.

[6] Miller-Rushing A, Primack R, Bonney R. The history of public participation in ecological research [J]. Frontiers in Ecology and the Environment, 2012, 10(6):285-290.

[7] Irwin A. Citizen Science: A Study of People, Expertise and Sustainable Developing [M]. Psychology Press, 1995:4-5.

[8] Gollan J, Bruyn L L D, Reid N, et al. Can Volunteers Collect Data that are Comparable to Professional Scientists? A Study of Variables Used in Monitoring the Outcomes of Ecosystem Rehabilitation [J]. Environmental Management, 2012, 50(5):969-978.

[9] Qianhui Qi. The Concepts and Essence of Key Competence [J]. Journal of curriculum education research, 2019(18): 235

[10] Devictor V , Whittaker R J , Beltrame C . Beyond scarcity: citizen science programmes as useful tools for conservation biogeography [J]. Diversity \& Distributions, 2010, 16(3):354-362. 